\title{
The Emergency of Authority on the Supervision of Old Wells Mining Policy in Indonesia
}

\author{
Shinta Hadiyantina \\ Administrative Law Department \\ Faculty of Law, Universitas Brawijaya \\ Malang, Indonesia \\ shinta_fh@ub.ac.id
}

\author{
Nandaru Ramadhan \\ Student in Master of Law \\ Faculty of Law, Universitas Brawijaya Malang, Indonesia \\ Malang, Indonesia \\ ramadhannandaru@gmail.com
}

\begin{abstract}
The old well drilled before 1970. Until now, there are still old wells that remain active for removing petroleum. The management of the old well is the authority of the central government. Ministry of Energy and Mineral Resources regulates the management of wells by issuing Regulation of the Minister of Energy and Mineral Resources Number 1 of 2008 on Guidelines of Petroleum Mining Concession to Old Wells.

The Consideration of Regulation of Minister of Energy and Mineral Resources Number 1 of 2008 on Guidelines of Petroleum Mining Business on Old Wells mandates to involve public participation in the process of petroleum mining at old wells. In fact, the ministerial regulation doesn't regulate further in relation to society's participation. The community also conducts petroleum mining in old wells, but it is illegal because it does not refer to the Minister of Energy and Mineral Resources Regulation Number 1 of 2008 on the Guidelines of Petroleum Mining Concession to Old Wells.

Local Government has a strategic position to regulate community participation in petroleum mining in old wells. The Regional Government must have a Regional Regulation, which accommodates the interests of the community as a traditional miners. However, it contradicts the Regulation of the Minister of Energy and Mineral Resources Number 1 of 2008 on the Guidelines of Petroleum Mining Concession to Old Wells.

The problems of this article are (1) How is the position of the miner's community on petroleum mining in the old wells? (2) How to revitalize the authority of local governments on petroleum mining in old wells? In accordance with the issues raised, this research is a doctrinal research or is also referred to as normative research.
\end{abstract}

Keywords - authority, supervision, policy, old wells mining.

\section{INTRODUCTION}

Indonesia has abundant natural resources and mineral resources, so that Indonesia is a country that is rich in mining materials. One of the mining materials attracting investors, both foreign investors and local investors, is petroleum. Petroleum mining in Indonesia has a positive impact on national and regional development. The positive impact of the existence of mining companies is to increase the country's foreign exchange, increase local revenue, accommodate employment, and increase the socio-economic, health and cultural conditions of the people living around the mine[1]. Based on data from the Ministry of Energy and Mineral Resources, the age of the petroleum industry has been more than 100 years[2]. Many oil wells have also been excavated and operated since before Indonesia's independence. The wells are still in operation today and are called old wells.

Old wells are oil wells drilled before 1970 and once manufactured and located on unprofitable fields in a Work Area bound to Cooperation Contracts and are not put into operation by contractors[3]. The philosophy of utilization of old wells according to the Directorate General of Oil and Gas is to increase production, optimize the utilization of old wells, community development, increase the Regional Income (RI) and increase the role of national small and medium entrepreneurs in the exploitation of old wells. In 2008, there were 745 active oil wells and 13,079 non-active old wells. Most of them are in the oil and gas working area of PT Pertamina. Others are in the Coperation Contract Contractor (CCC) company working area. The old wells that spread in various locations in Indonesia those operated until 1970[4].

Based on Article 14 paragraph (3) of Law Number 23 of 2014 on Regional Government, Government Affairs in energy and mineral resources related to the management of oil and natural gas become the authority of the Central Government[5]. In Attachment to Law Number 23 of 2014 on Regional Government, the Division of Constanten Government Affairs between Central and Provincial and Regency / Municipal Governments, in letter CC divides the governmental affairs of energy and mineral resources, subsection number 3 on oil and natural gas, granting the authority of oil and gas to the central government. Provincial and Regency / Municipal Governments do not have authority in oil and gas.

The central government, through the Ministry of Energy and Mineral Resources, regulates the utilization of old wells by issuing Regulation of the Minister of Energy and Mineral Resources Number 1 of 2008 on the Guidelines of Petroleum Mining Concession to Old Wells. Based on the Ministerial Regulation, management of old wells is carried out as shown the scheme below: 


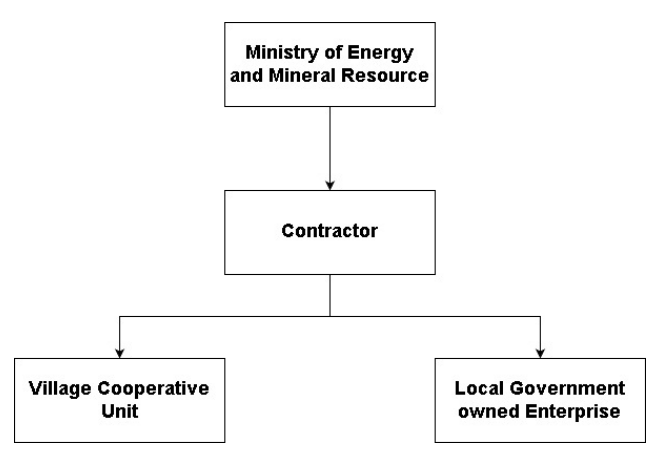

Old well management is carried out by contractors. If contractors do not attempt and produce petroleum from old wells, then the Village Cooperative Unit (VCU) / Local Government owned Enterprise (LGOE) can cultivate and produce petroleum based on the Agreement to Produce Petroleum with contractors[6]. VCU / LGOE must submit all oil produced from old wells to the contractors[7]. Then, the contractors are obliged to provide compensation services to VCU/LGOE for the entire production of petroleum from the results of the implementation of producing petroleum which is held by VCU/LGOE[8].

In fact, the management of old wells does not happen like the above scheme. An example is the management of an old well in Wonocolo, in Blora, and in the Pasir Putih Village. Wonocolo Village, Bojonegoro Regency is a traditional oil drilling location held by residents. The drilling in this 11.37 square kilometers village has been carried out since the Dutch colonial era. After the Japanese occupation, old wells were managed by residents with the permission from the local regent until finally became the authority of the Directorate General of Oil and Gas in 1987. At present, the oil wells are under Pertamina Exploration and Production (EP) Asset 4 Field Cepu. The management of old wells is carried out by miners, and the results are not handed over to Pertamina, because the price offered by Pertamina is low. There are also traditional refineries, which offer higher purchase prices, so miners choose to hand over the oil to the owner of the refinery[9].

A Study on the impact of traditional management of old wells by Communities in Wonocolo Field Cepu Region Java (2009) mentions several possible causes of illegal sale, including[10]:

1. The cost of shipment and transportation received by miners after cut by VCU administration fees and regional development funds, is still far below the price if sold directly to other parties other than Bogo Sasono VCU;

2. Some of the miners began to shift from being only miners to miners and refiners, so that they would earn more profits compared to depositing to VCU;

3. There is another party that causes the miner not to dare to deposit crude oil to VCU Bogo Sasono VCU. They included capital owners and regional people who had previously migrated and have now returned to Wonocolo Village, who already possesses a lot of knowledge from the outside world;

4. Relations between miners and Bogo Sasono VCU are less harmonious. This can be seen from the business of the miners to form another VCU, such as Patra Jasa Jaya VCU. But this VCU has not been able to operate because it has not gained permission from the Government in accordance with the provisions of Law Number 22 Year 2001 concerning Oil and Gas;

5. The transaction of distillate crude oil out of the area greatly benefits miners and refiners, but harmed the government (Bojonegoro District Government and PT Pertamina EP Cepu).

Another example is the management of old wells in Blora Regency. Old wells in Blora regency are also managed by miners' associations. The contractor is PT Pertamina EP. PT Pertamina EP has licensed petroleum management to the miners (community groups) on the grounds of a governance lease with a community to about 282 wells. Pertamina EP party has not explained the existence of old wells produced by miner's community. Whereas based on the Regulation of Minister of Energy and Mineral Resources Number 01 of 2008 and PTK 023 / PTK / III / 2009, only VCU or LGE that are allowed to cultivate and produce oil in old wells[11].

Gampong Pasir Putih is located in Ranto Peureulak subdistrict, East Aceh. Old wells here are mostly controlled by groups of citizens. Oil wells which are illegally managed by the citizens, Illegal in a sense that the petroleum exploitation activity, are not carried out according to the stage and through the mechanism specified in the legislation. On Wednesday, April 25, 2018, there was a blowout event followed by the fires in the wells managed by the residents. This event is not the first time in Aceh, but in terms of its victims, this incident is the largest. The total causalities account for 20 people dead, and dozens of others suffering burns are being hospitalized[12].

Those three examples of old well management have something in common, that is the involvement of traditional miners who are members of the mining community. These traditional miners cannot be separated in the petroleum production process in the old wells. One logical reason is that old wells are remaining of boreholes that were initially abandoned because they had been used up, but they are still able to extract petroleum. So the traditional miners took place, and in 1987 the auspices became the authority of the Directorate General of Oil and Gas. The problem that arises is not accommodating the miners' association in the Regulation of the Minister of Energy and Mineral Resources Number 1 of 2008 on Guidelines for the Concession of Petroleum Mining in Old Wells. The next problem is related to the authority of the local government, whose territory becomes a place for mining old wells. Local governments have limitations in the case of violations committed in the field. If the petroleum produced is not handed over to the contractors, then both the central government and local governments are equally at a disadvantage.

\section{PROBLEMS}

1. How is the position of the mining community in petroleum mining in the old well?

2. What can be done to revitalize the authority of local governments in petroleum mining on old wells?

\section{LITERATURE REVIEW}

\section{A. Theory of Authority}

The terms power, competence, and authority are often equated. The terms authority, and power are often 
exchanged. Power has the meaning of the rule and the ruled[13].

Based on the above understanding, there can be power that has nothing to do with the law. Henc van Maarseven mentions blote match[14] is a power that had nothing to do with the law, whereas according to Max Weber, a power that had something to do with the law was called rational or legal authority. Rational / legal authority is an authority based on a legal system that is acknowledged and obeyed by the community, in which rules are also strengthened by the state.

In public law, power is concerned with authority[15]. Power and authority have the same meaning. Power and authority inherent in the legislative, executive, and judiciary are formal powers. Power is the main element in the process of governance, while the other elements are[16]:
a. Law;
b. Authority;
c. Policy;
d. Justice;
e. And Honesty

Power is the driving force of the state administration in order to create de staat in beweging (country in a state of movement) so that the state can work, and performs its service to its citizens. According to Miriam Budiardjo, power is the ability to influence the behavior of others to follow the goals of his desires[13]. To exercise power, it takes a ruler or an organ. The State is conceptualized as the set of een ambten complex (positions) by a number of officials based on subject-duty construction[16].

Thus, power has two aspects, namely political aspects and legal aspects, while authority is only based on law. Power can be derived from the constitution or outside the constitution, for example through a coup or war, while authority comes from the constitution.

Authority is formal power derived from legislative power (by law) or derived from administrative executive power. Authority is power over a field of government by a certain group of people[17]. Ateng Syafrudin believes there is a difference between the notion of competence and authority[18]. Authority is a formal power derived from legislation, and competence is part of that authority. Authority exists within the scope of public law, speaks of government decisions as well as the performance of tasks established in legislation. By juridical, authority has a meaning of an ability derived from legislation and cause legal consequences[19]. According to H.D. Stoud, in a brief, authority is all the rules concerning any implementation by the government as the subject of public law.

\section{B. The Concept of Local Government}

The concept of government as an institution in the life of the state and society tend to be manifested in the form of governance. Bureaucracy stands with the understanding of being the most active party in the management of daily state power. Bureaucracy is also placed in the executioners position to the decisions formulated and issued by political leaders.

Governance has a strategic and essential value in the implementation of the State. According to Siagian[20], bureaucracy is a large part and organization is used to refer to the entire government apparatus in a country. According to Max Weber in Parenti[21], the outline of the bureaucratic characteristic is:

a. Systematic mobilization of human energy and material resources to realize policy objectives or plans that are explicitly defined;

b. Utilization of trained career personnel who hold positions not based on inheritance and has been limited to specific jurisdiction;

c. Specialization of expertise and division of labor that is responsible to an authority or constituency.

It can also be said that governance can be interpreted as a process in which the government carries out its function to achieve certain goals and objectives. Various agencies (Institutions) were formed to carry out their respective mission and function in the framework of the goals of the state and the ideals of the nation. Furthermore, the Government, or governance in the narrow sense, is the holder of executive power, while in the broad sense, all of its Institutions and activities in a state. So it also concerns matters relating to legislative and judicial power.

A law-based governance is a government that upholds the supremacy of the law and is not based on its human will. Sudikno Mertokusumo mentioned it with the title governance not by man but by law[22]. In a state based on law, the law is placed as the highest reference in the administration of the state and its government (rule of law). In this case it is embraced to a doctrine of the rule of law which places the law at the highest position. The law is used as guiding principle for all activities of organs of the State, government, officials, and the people. This is in line with the principle of power division or distribution of power adopted by the 1945 Constitution which is intended to limit and prevent the possibility of accumulation and abuse of power in government agencies / institutions or government officials.

Lord Acton, in relation to the aforementioned as quoted by Sri Soemantri Martosoewignjo, stated "Power tends to corrupt; and absolute power tends to corrupt absolutly", which in essence means no matter how small the power, it tends to be misused. Regarding the division of power of government, it may occur horizontally between the state high institutions or on the basis of joint expertise between departments, as well as vertically or on the basis of regional joints between the Central Government and the local Government in the Region. In this connection, the birth of a regional government in the territory of Indonesia is essentially a consequence of the State of Indonesia as a legal state based on Pancasila.

The local / regional government that we know today is derived from the development of government practices in Europe in the $11^{\text {th }}$ and $12^{\text {th }}$ centuries. At that time, regional units emerged at the basic level which naturally formed a government institution. Initially the regional units were a self-managed community units from the community of the population. In the next development, these community units were incorporated into the State's administration system of a sovereign State.

Large and complex organizations such as the State of Indonesia will not be efficient if the administrative and political authority is placed in the hierarchy of the central government / organization. In order for authority to be implemented efficiently and accountably, some authority is 
left to regional governments called decentralization. Hence, decentralization is the transfer of political and administrative authority from the central government to regional governments[23].

Rondinelli formulates that[24], "Decentralization is the transfer of planning, decision making, or administrative authority from the central government to its field organizations, local government, or non-government organization."

\section{DISCUSSION}

Position of the Mining Society within the Petroleum Mining of Old Wells

The legal basis for the management of petroleum in old wells when used as a reference for its implementation, are as follows:

\section{Law Number 22 of 2001 on Regulating Oil and Gas;}

Government Regulation Number 42 of 2002 which regulates the Agency for the Implementation of Upstream Oil and Gas Business Activity;

Government Regulation Number 34 of 2005 regarding Amendment to Government Regulation Number 35 of 2004 regarding Upstream Business Activities of Oil and Gas;

Regulation of the Minister of Energy and Mineral Resources Number 01 of 2008 which regulates the Guidelines of Petroleum Mining Concession to Old Wells.

The legal basis used as a regulation that regulates specifically and is used as a guideline in the implementation of petroleum management in old wells by VCUs and LGEs is the Regulation of the Minister of Energy and Mineral Resources Number 1 of 2008 concerning Guidelines for Petroleum Mining Exploitation in Old Wells.

In the Regulation of the Minister of Energy and Mineral Resources Number 1 of 2008, it regulates the guidelines for the exploitation of producing oil in old wells for VCU and LGOE, if the contractor is unable to cultivate and produce petroleum in the old well. The Regulation of the Minister of Energy and Mineral Resources Number 1 of 2008 also includes an application for approval to the contractors with a copy to the Minister represented by the Director General and the Implementing Agency which is accompanied by administrative and technical documents, the agreement to produce petroleum by contactors with VCU or LGOE, the implementation of producing petroleum, compensation for services in producing petroleum, and coaching and supervision by contractors. Concern on administrative and technical documents has also been described in this the Regulation of the Minister of Energy and Mineral Resources.

The rules in the Regulation of the Minister of Energy and Mineral Resources Number 1 of 2008 on Guidelines for the Concession of Petroleum Mining in Old Wells states that the parties involved in the management of petroleum mining in old wells are contractors, LGOE, and VCU. This is different from the practice in the field, where there is an involvement of miners' communities in the petroleum mining process in old wells. The schemes that occur in the community are as follows:

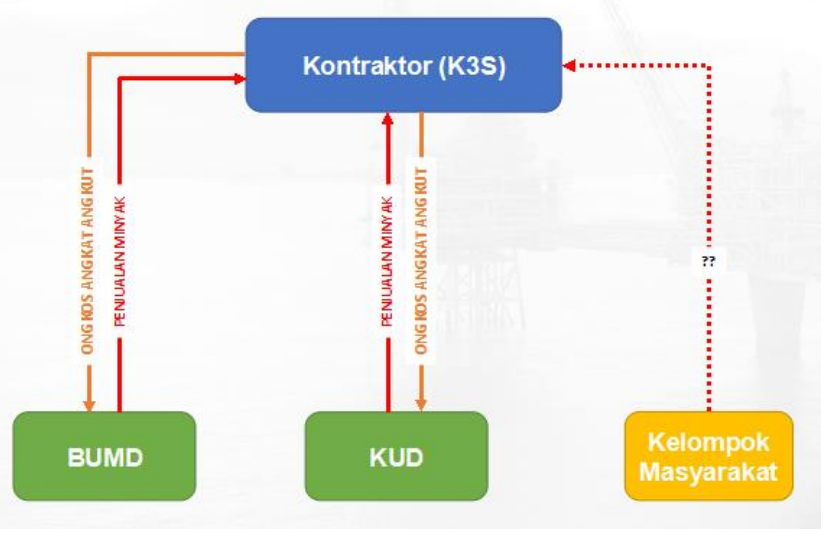

The position of LGOE and VCU to contractors is very clear. The legal relationship occurs based on a contract, where the contractor will get petroleum, while the LGOE / VCU will get the cost of shipment and transport. Freight charges are remunerated for petroleum services deposited to contractors. The amount of the service fee is determined fairly based on the agreement of both parties regulated in the Agreement to Produce Petroleum[25].

Unlike the clear position of VCU and LGOE, the legal position of the mining association is not regulated in the ministerial regulation. Therefore, basically mining activities conducted by community groups are illegal. The nonregulation of mining activities conducted by community groups is a weakness of the minister's regulation.

In the consideration of the Regulation of the Minister of Energy and Mineral Resources Number 1 of 2008 on Guidelines for the Concession of Petroleum Mining in Old Wells, it was stated that "in order to optimize the production of Petroleum in a working area in which there are Old Wells and to improve the welfare of the communities around the old wells site, it is necessary to do petroleum mining in old wells by involving the participation of the surrounding community." From the aforementioned considerations, the government realizes the importance of including the participation of the surrounding community, but the contents of the ministerial regulation do not regulate the participation of the community in the oil field at the old well.

Community's participation is inevitable in petroleum mining in old wells. If this is not immediately addressed, the government, regional government and community groups will be harmed equally. The obtained petroleum is often not deposited to Pertamina, which is detrimental to the government, both central and regional. In addition, the safety of miners is also at risk because the process is done traditionally. Local governments have a strategic position to regulate community groups in the petroleum mining process in old wells.

Revitalization of Regional Government's Authority on Petroleum Mining in Old Wells

The State controls the earth, water, and natural resources contained therein in accordance with article 33 paragraph (3) of the 1945 Constitution of the State of the Republic of Indonesia. The State authorizes the government to undertake exploration or exploitation activities (upstream business activities) on the basis of mining rights. The government as the holder of the mining authority forms the implementing agency. The implementation of the tasks, functions and 
organization of the Implementing Agency for upstream oil and gas business activities is transferred to the Minister of Energy and Mineral Resources[26]. The Executing Agency is an entity formed in the field of upstream business activities to perform supervision[27].

The Central Government has the authority in the management of petroleum in old wells which have been transferred to the Minister of Energy and Mineral Resources. In the management of petroleum in old wells by VCU and LGOE, the local government in question is the District Government / Regent. District Government has authority in giving recommendation to oil concession at old well by VCU and LGOE.

The Central Government (Minister of Energy and Mineral Resources) offers a working area with the consideration of the Implementing Agency. The Minister of Energy and Mineral Resources shall consult with the Regional Government whose administrative territory covers the area of work offered to a business entity or a permanent establishment. PT Pertamina (Company) makes an application to manage the offered work area. The holder of the working area in petroleum management at the old well in Blora Regency is PT Pertamina EP which is a subsidiary of PT Pertamina, as the Contractor holding the Cooperation Contract.

Regarding the management of petroleum in old wells, the Office of Energy and Mineral Resources has authority in the management of petroleum in old wells, namely supervision and guidance in terms of general authority. While its special authority is to provide technical recommendations for the submission of old well management. The Department of Energy and Mineral Resources has a role to play in the management of the old well, which is to socialize the conditions of the management of the old well according to the rules, and to provide assistance as an expert witness in the Court in the case of unlicensed petroleum mining.

The authority owned by the district / city government is to provide recommendations to VCUs and LGOEs to contract with contractors. LGOE and VCU involvement is a way to involve community participation. In addition, the district / municipality governments also have the authority to conduct guidance and supervision of LGOE and VCU that produce petroleum[28]. But in practice, there are community groups outside the LGOE and VCU who also participate in mining activities.

The contractors should know if there is a group of miners who control the old wells, but there is omission. The location of blow out in Aceh is in fact located in PT Pertamina EP Asset Oil and Gas working area 1. That is, as a Cooperation Contract Contractor, PT Pertamina EP should know best, what and why it happened in its working area. Because, referring to the Regulation of the Minister of Energy and Mineral Resources Number 1 of 2008, the petition for the exploitation of oil wells shall also be directed to contractors. Simple logic is because the contractor is the "ruler" over the oil and gas working area. Therefore, if there is a case of petroleum cultivation within its territory, it should be the contractor who first takes action. Whether in the form of prevention, reporting, or other appropriate actions as the concession holders. The author believes, PT Pertamina EP Asset 1 is aware of this. So are the law enforcement officers and other stakeholders, even the government at the village level. Yet, back to the above dilemma position. The economic benefits (das sein) have overcome legal norms (das sollen).

The regional government should make local regulations related to community groups that conduct mining in old wells. Such illegal mining process should not be allowed to continue, as it would harm the government and threaten the safety of miners themselves if they engage in illegal activities. This community group should be incorporated in the LGOE or VCU, so that their safety is also guaranteed in the mining process. In addition, local governments must also be firm to crack down on those who buy petroleum from the public.

\section{CONCLUSION}

From the discussion above, it can be concluded as follows:

1. The position of the miners' association is not regulated in the Regulation of the Minister of Energy and Mineral Resources Number 1 of 2008 on Guidelines for the Concession of Petroleum Mining in Old Wells. The Regulation of the Minister of Energy and Mineral Resources Number 1 of 2008 on Guidelines for Petroleum Mining Exploitation in Old Wells in the preamble states that it is necessary to include community participation in the management of petroleum mining in old wells, but in the main section, community participation is not explained further.

2. District/City Regional Governments have a strategic position to provide protection to the mining community. Each region needs to make regional regulations related to the position of community groups that conduct petroleum mining in old wells

\section{REFERENCES}

[1] Salim HS, Hukum Pertambangan di Indonesia. Jakarta: Rajawali Pers, 2010

[2] "Potensi Minyak Bumi Indonesia 2015," 2016. [Online]. Available: http://www.energi-ku.com/2016/07/potensi-minyak-bumi-indonesia2015.html.

[3] Article 1 point 2 of Regulation of the Minister of Energy and Mineral Resources Number 1 of 2008 on the Guidelines of Petroleum Mining Concession to Old Wells. .

[4] Tim Komunikasi ESDM, "13 ribu Sumur Minyak Bumi Tua ditawarkan Kepada KUD dan BUMD,” 2008. [Online]. Available: https://www.esdm.go.id/id/media-center/arsip-berita/13-ribu-sumurminyak-bumi-tua-ditawarkan-kepada-kud-dan-bumd.

[5] Article 14 paragraph (3) of Law Number 23 of 2014 on Local Government (State Gazette of the Republic of Indonesia of 2014 Number 244, Additional State Gazzete of the Republic of Indonesia Number 5587). .

[6] Article 2 of Regulation of the Minister of Energy and Mineral Resources Number 1 of 2008 on the Guidelines of Petroleum Mining Concession to Old Wells. .

[7] Article 10 paragraph (1) of Regulation of the Minister of Energy and Mineral Resources Number 1 of 2008 on the Guidelines of Petroleum Mining Concession to Old Wells. .

[8] "Article 11 paragraph (1) of Regulation of the Minister of Energy and Mineral Resources Number 1 of 2008 on the Guidelines of Petroleum Mining Concession to Old Wells."

[9] Ika Ningtyas, "Jejak sumur minyak tua peninggalan Belanda," 2017. [Online]. Available: https://beritagar.id/artikel/laporan-khas/jejaksumur-minyak-tua-peninggalan-belanda.

[10] Suprapti, "Penyelesaian Sengketa Pengelolaan Sumur Tua Secara Tradisional Oleh Masyarakat di Desa Wonocolo Bojonegoro Dari 
Aspek Hukum," vol. 4, no. 2, pp. 121-134, 2011.

[11] P. M. Ayu, "Implementasi Kebijakan Pemerintah Terkait Pengelolaan Minyak Bumi Pada Sumur Tua Oleh VCU dan BUMD di Kabupaten Blora (Studi di Dinas Energi dan Sumber Daya Mineral Kabupaten Blora)," 2015.

[12] Bambang Antariksa, "Paradoks Pengusahaan Sumur Tua Migas Artikel ini telah tayang di serambinews.com dengan judul Paradoks Pengusahaan Sumur Tua Migas, http://aceh.tribunnews.com/2018/04/30/paradoks-pengusahaansumur-tua-migas. Editor: bakri," 2018. [Online]. Available: http://aceh.tribunnews.com/2018/04/30/paradoks-pengusahaansumur-tua-migas.

[13] Miriam Budiardjo, Dasar-Dasar Ilmu Politik. Jakarta: Gramedia Pustaka Utama, 1998.

[14] Suwoto Mulyosudarmo, Kekuasaan dan Tanggung Jawab Presiden Republik Indonesia: Suatu Penelitian Segi-Segi Teoritik dan Yuridis Pertanggungjawaban Kekuasaan. Surabaya: Universitas Airlangga, 1990.

[15] Philipus M Hadjon, "Tentang Wewenang," Surabaya.

[16] Rusadi Kantaprawira, Hukum dan Kekuasaan. Yogyakarta: Universitas Islam Indonesia, 1998

[17] Prajudi Atmosudirdjo, Hukum Administrasi Negara. Jakarta: Ghalia Indonesia.

[18] Ateng Syafrudin, "Menuju Penyelenggaraan Pemerintahan Negara yang Bersih dan Bertanggungjawab," J. Pro Justicia Ed. IV, p. 22.
[19] Indroharto, Asas-Asas Umum Pemerintahan yang Baik, dalam Paulus Efendie Lotulung, Himpunan Makalah Asas-Asas Umum Pemerintahan yang Baik. Bandung: Citra Aditya Bakti, 1994.

[20] Sondang P. Siagian, Patologi Birokrasi. Jakarta, 1998.

[21] Michel Parenti, Democracy for the Few, Fifth. New York: St Martin's Press, 1988

[22] Sudikno Mertokusumo, "Upaya Meningkatkan Supremasi Hukum," Majalah Justitia Et Pax, Fakultas Hukum Univ. Atmajaya, Yogyakarta, Yogyakarta, p. 2, 2000.

[23] Hanif Nurcholis, Teori dan Praktek Pemerintahan Daerah. Jakarta: Grasindo, 2005.

[24] Dennis A. Rondinelli, "Government Decentralization in Comparative Perspective Theory and Practice in Developing Countris," Int. Rev. Adm. Sci., vol. 47, no. 2, p. 18, 1981.

[25] Article 11 Paragraph (2) of the Regulation of the Minister of Energy and Mineral Resources Number 1 of 2008 on the Guidelines of Petroleum Mining Concession to Old Wells. .

[26] Presidential Decree Number 95 of 2012 on the Transfer of Duty and Function in Oil and Gas Upstream Business Activity, Article 1, State Gazette of the Republic of Indonesia of 2012 Number 226. .

[27] Law Number 22 of 2001 on Oil and Gas, Article 1 Paragraph 23, State Gazette of the Republic of Indonesia on 2001 Number 136. .

[28] Article 14 Paragraph (3) of the Regulation of the Minister of Energy and Mineral Resources Number 1 of 2008 on the Guidelines of Petroleum Mining Concession to Old Wells. 